\title{
Depiction of Victorian Era in the Novel Great Expectations by Charles Dickens
}

\author{
Farhana Haque ${ }^{1}$ \\ ${ }^{1}$ English and Humanities, Brac University, Bangladesh \\ Correspondence: Farhana Haque, English and Humanities, Brac University, 1343, Bangladesh. Tel: 880-1731- \\ 168-418. E-mail: dhak_121@yahoo.com
}

Received: June 24, 2018; Accepted: June 22, 2018; Published: July 31, 2018

\begin{abstract}
Charles Dickens' Great Expectation actually did reflect the Victorian society and therefore the morality of that era's people inside of the novel. Since we know that Victorian era basically present some features such as virtue, strength, thrift, manners, cleanliness, honesty and chastity. These are the morals that Victorian people used to hold with high esteem. In this novel Great Expectations, Dickens has created some Victorian characters whom we have seen both in good working way or not at all. But the protagonist named Pip was dynamic and he went through some several changes and dealt with different and significant moral issues. Somehow Pip left behind all the values he was raised with. Because Miss Havisham and Estella have corrupted Pip with rich life. Greed, beauty and arrogance were his ingredient of immoral life. The other characters like Joe and Biddy were static characters throughout the entire novel and became noticeable to be the manifestation of what we call as ideal Victorians. The main heroin of this novel was Estella with whom Pip thought he had some love connection. Hence, Estella has been presented as a good in the sense of potentiality and turned morally bad. Miss Havisham, who was basically a corrupt woman and she engraved the center of the novel. Great Expectations did disclose how was the situation of Victorian society through some important features such as higher class, corrupted judicial system between rural and urban England. Here in this novel, Dickens was concern about the education system in Victorian era where the lower class people get less opportunities of getting proper education. From the beginning to the end of this novel, Dickens explored some significant issues regarding higher and lower class system of Victorian society which did fluctuate from the greatest woeful criminal named Magwitch to the needy people of the swamp country, where Joe and Biddy were the symbol of that regime. After that we can proceed to the middle class family where Pumblechook was the person to represent that regime. Last but not the least Miss Havisham symbolized and bear flag of very rich and sophisticated Victorian woman who has represented the higher class society in the novel Great Expectations. Hence we can say Great Expectations has talked and displayed the class system of Victorian England and the characters of this novel therefore also did uphold the true reflection of Victorian era.
\end{abstract}

Keywords: Great Expectations, Victorian Society, Pip, Estella, Miss Havisham, Upper class, Lower class

\section{Introduction}

Great Expectations is one of the finest Victorian themed novel. Dickens has created his main protagonist Pip as a dynamic character. His characteristics got changed over time and in one point we saw Dickens made Pip as a hubris man since he was feeling so odd after seeing his childhood friend Joe who came to London. Pip's another friend Biddy wrote a letter about the visit of Joe in London but Pip was not happy. Instead of getting happy Pip felt uncomfortable. Inside of his mind he thought and wished for not meeting with Joe. Because Pip felt Joe need not see his sophisticated society where he used to live. Pip's haughtiness did grow and also rose to such an extent that he has pondered about offering Joe's some money. After meeting with Joe, Pip did behave very strangely and also showed no interest to him. As a result Pip felt a sense of embarrassment for Joe's presence in his place. He felt very uneasy because he thought Joe's behaviour was uncouth and also he didn't like his coat and antiquated hat either. Therefore it has been so crystal clear towards Joe regarding Pip's attitude of ignoring him very badly. That is why Joe didn't want to stay in Pip's room for that night. Again we saw Pip's arrogance when he paid a visit to Joe's home town and as well as didn't settle down with Joe. Instead of that he took a room at an inn. Nonetheless, the surprising facts of Victorian society was centered towards the people of higher class or gentlemen who used to get different treatment from judicial system. Hence they actually used to get less punishment from the lower class people who were entitled with comparatively unrelenting punishment. For example Magwitch became the victim to injustice and merciless law enforcing agency. The judicial system gave Magwitch the most rasping 
penalty which was almost 14 years of imprisonment than the original villain Compeyson which was 7 years imprisonment. This injustice eventually happened. Thus we have came to know about Magwitch's previous crimes and how he carried previous criminal reports apart from his recent crime presented towards the end of this novel. on the other hands Compeyson looked like a good man with superior and elite class ancestry. The prime issue did exist between the poor and rich people in England. This difference between lower and higher class came after judging both parties life styles. At first we can discuss about the rural people who were very simple and innocent. They were also honest, caring and docile. But the people of the city like London became fake and complicated. For example, whenever pip has arrived in the city then he looked around of the metropolis and he was not much impressed by the town where Mr. Jaggers got his office and the area was named by "Little Britain,". The locality also has been known as a tainted place. To be honest Mr. Jaggers' office was in a very gloomy area. In Jaggers place, there was an middle aged housekeeper whose age was forty and she was always busy in keeping her eyes attentive on her lord and especially when she used to be in the dining-room. While Pip was in Jaggers home he also did notice about Jaggers concern about everything, therefore he used to do all things by his own ways and then disseminated everything himself. Jaggers was one of the sagacious lawyer who did take out whatever information he wished from each of his guests. In this novel Great Expectations the depiction of rural England has been presented through Pip's sister's family which was known as Joe's family. At first when we have started to read the novel we came to know about an orphan boy whose name was Pip, and he lived with his sister and her husband named $\mathrm{Mr}$ and Mrs. Joe Gargery who used to live in a marsh down by the river. So on the other sides we saw the rich people were harsh and selfish. And here lies the main characteristics of Victorian society. In Great Expectations there were some characters who were decorated with the characteristics of greedy and power achieving people. Pip has been visited Miss Havisham's house for the second time, and did find some relatives of Miss Havisham, but Pip felt those people were "toadies and humbugs".

All those relatives were seeker after money. They all wished to get financial benefits from Miss Havisham. Once they all went to her birthday in order to win her goodwill. But they got disdain inside of their heart for Miss Havisham because of her prosperity. Their visit to Miss Havisham was nothing but based on greed, as well as they hoped to satisfy her enough to be given some of her money at her death. So it is almost clear that Miss Havisham was the victim even of her lover had greed for money. And eventually that greedy lover did stole lot of her money and then abandoned her. Towards the end of this novel Miss Havisham did learn that the possession of money can't stop to face brutality and misery. Materialistic notions has been seen in Miss Havisham and her kinsman's lives. She had no good relation with her relatives but only sustained for money, power and greed with her relatives which was based on money and power. Those relatives didn't show hatred directly but inside of their mind they did despise her and only used to keep contact with her for taking some privileges from her. So we can say those people are the perfect symbols of Victorian society which the author has portrayed very clearly in Great Expectations.

\section{Portrayal of Education in Victorian Era in Great Expectations}

In the novel Great Expectations the depiction of teachers got symbolized by various institutional opportunities. There was one character called Mr. Wopsle's great aunt who did provide less chance to teach the lower class people and therefore she used to give irrelevant education to her students. There were some different types of study which has been remained in Victorian society of England but those were restrained some people especially the poor ones. The protagonist of this novel called Pip was lucky because he got an inexplicable patron who paid for his education to make him a gentleman. And he was luckily upgraded to one such opportunity when a mysterious patron paid for his "gentleman's education." Mr. Pocket, a Cambridge graduate, did provide the academic knowledge that also matched with his own avocation. This very education actually provided egocentric persons by whom there will be no benefits in society. In relation to that ideology we can say, Pip was not actually understanding the meaning of scholarly education and left him with no benefits for society. However, in this novel we saw Dickens yielded a clear scenario of the lower class people who did struggle with the essential opportunities regarding education.

\section{Representation of Victorian Era in the novel Great Expectations}

Dickens' Great Expectations refers to one of several reflective books of Victorian era. This book is a very successful illustrative of its own time. Dickens wrote this novel Great Expectations in 1860 based on the orphan boy Pip from his childhood to adulthood. The book did represent the typical Victorian elements such as social class difference, industrialization, Victorian values and also the status of women in that era. At the very beginning of the novel we did encounter with a common low-class family. They lived in a village among swamps. Mr. Joe was a blacksmith and his wife (the sister of Pip) who was a typical Victorian low-class housewife. She was submerged under the household duties and always used to complain about not being able to take off her apron 
because of her harsh duties, she was always disappointed and often did beat Pip. After that, we have encountered with high-class, well-dressed, well-dancing women like Miss Havisham and Estella through the on ahead of the book. These two different families were also the first examples of the existence of social classes in the society. Therefore to some extent we got to know that Victorian era means social hierarchy. First of all we saw Gargery family who actually symbolized as a poor, uneducated existence in a village. While on the other hands, Miss Havisham did live in a mansion called Satis House. Another family named 'The Pockets' whose house was full of servants. Estella was a young lady who used to do dances well and educated from abroad. The main protagonist called Pip became rich after the secret benefactor gave him money. He got changed and started to live his life in a luxarious style. He had other women in his life along with Estella. And those other women in Pip's snobbish life in London represented the typical high-class Victorian women. After seeing the two different lives in early years of his life, Pip did choose to shift to the upper class. He expected to become a 'gentleman' because he has all the values appreciated by the society in order to have Estella and an upper class lifestyle. Pip was very impressed about London which did remind us about the effects of Industrial Revolution and immigration. When he came to London, he was surprised and was not satisfied with the unbelievable and unavoidable crowd (resulting from immigration for job) and awful smell (coming from sewage due to the factories): 'I was scared by the intensity of London. I think I might have had some faint doubts whether it was not rather ugly, crooked, narrow, and dirty.'(pg. 138) The shadowy streets of Smithfield did disarrange him. But the Satis House, Wemmick's house (like a castle), and other ornamented houses reminds us the taste of architecture of Victorian age. While on the other hands, it is very sad not to notice some of important themes of Victorian era such as child labor, prostitution, colonialism etc. in Great Expectations. But, Dickens used colonialism in Great Expectations as a narrative device. A transported convict exactly did meet the need for a patron who can make a valuable fortune yet who has to endure as anonymous, and of whom Pip will eventually be remorseful. The capital law against returning from installation did enhance the impact of the later chapters, when Pip did shed his ostentations as well as his wealth.' Thus like Dickens so many Victorian authors have used the colonies as places to shift burned-out characters or from which to redeem characters, used this aspect of colonialism as the dramatic base for his novel. In other words, colonialism was used not as a theme but a narrative device in Great Expectations. Also, Dickens used the other themes mentioned above in his other works. For example, Oliver Twist - child labor, destitution etc.

\section{Victorian women in Charles Dickens Great Expectations}

Charles Dickens did create some world famous characters through his novels. Therefore he stands as the master in handling some master piece characters through his novels. As we know the ideal Victorian womanhood means, she has to be an angel in the house also should be a moral, yielding, and domestic paragon. While on the other hands the Victorian middle class refers to the women who should be confined to the home for protecting them from the unethical influences of the world in order to exercise their good influence on their husband and children. Hence it has to be believed that through them the society will be proficient from every sides in a larger way. In Great Expectations Dickens did portray about the various outlook of Victorian women who were beyond class lines. Although he depicted the powerful pictures of a very different outlook of Victorian women who go beyond class lines, he provided powerful portraits of crafty and shrewd women without any softness capacity for showing compassion and these were the characteristics of ideal Victorian women. Here in this section i would like to discuss about Victorian women's social status through the intense study of the chief women characters of Dickens' Great Expectations. Mrs. Joe, Pip's sister, was one of the important female characters who often did complain about her situation. She was presented in the novel with full of anger, indignation and as a comic figure or as a domestic tyrant, but it all has been seen as deriving from the loss of her parents and brother. The second another important character was Estella who did experience a strange upbringing. The third character was Miss Havisham whose behaviour was bizarre and compulsive, therefore she did remain constantly in pain, agony and suffering. Apart from them there are other female characters like Biddy, Clara, Mrs. Pocket and Molly those who have their shady deal of the behaviour of men and the suppositions of society. Dickens was the master of bright smiles and most unselfish tears. His women characters were so varied and full of different attitudes that they would make situation ethical or unethical and glowing or the worst. In the writing style of Dickens we have seen so many significant features such as the relation between literature and his fellow-men. Also he inspired them with compassion, charity, Sweet attitude and goodwill. He had the magic to generate such a realistic and individual characters and that is why he is considered next only to Shakespeare. In Great Expectations Mrs. Joe has been presented as mean, pretty, not grateful and eventually feeling less creature. To give the evidence of her nature i would quote some lines of Mrs. Joe. She remarked in the novel Great Expectations: "What did you say? Cried my sister, beginning to scream. What did you say? What did that fellow Orlick say to me, Pip? What did he call me, with my husband standing by? O! O! O! Each of these exclamations was a shriek; and I must remark of my sister, what is equally true of all the violent woman I have ever seen that passion was no excuse for her because it is undeniable that instead of 
lapsing into passion, she consciously and deliberately took extraordinary pains to force herself into it, and became blindly furious by regular stages; what was the name he gave me before the base man who swore to defend me? O! Hold me! O!” (p.112). Hence the reality of Mrs. Joe was very touching. Despite the intensity of Mrs. Joe's feelings there was no real human feeling involved. The second important character was Estella, who has observed a strange breeding. She got the idea of her true parentage and did live in the extraordinary setting of Satis House, also was restricted from other children and seeing the world only after Miss Havisham instruction to her. Compared to Mrs. Joe's bad mood with Estella's coolness: 'You must know', said Estella, condescending to me as a brilliant and beautiful woman might, 'that I have no heart - if that has anything to do with my memory". (p.235)

Here, Estella had no feelings of anger, she didn't have the feelings of disdain, and we can say she had no feelings about anything. The combination between both the characters which have been constructed from working class and also the upper class and this thing did create a sense in the novel. That very sense reminds us that women are not only the existence who are confined to do sympathetic and domestic deeds but also they often come up with completely opposite way in front of the society. Ironically, life among the higher and superior classes did not render redemption for Estella. Instead, she has been victimized twice by the embraced class. She needed to raised by Magwitch a man who was having inner nobility, but instead of that she has been raised by Miss Havisham, therefore she destroyed her potentiality to express emotion and communicate generally with the world. As a villain character Miss Havisham was lonely from long years and nursing her indignation to plan of taking revenge by her influence to control Estella's feelings. Her behaviour was also bizarre and obsessive therefore she did remain constantly in her sufferings and agony. Thus we can see that Charles Dickens did portray the realistic woman character like Miss Havisham who was psychologically convincing, though an eccentric. Assuredly, there are women in society who have been abandoned by their lovers and then they become habituated with frustration happened out of their bitter experience. Miss Havisham could not reunite herself to the disgraceful manner in which she was treated by her false-hearted lover. It was therefore quite natural for her, mentally constituted as she was a woman who only used her heart and brain to avenge herself upon the entire male sex. There was no implausibility in her to adopt a child and then determined wreak her nature of taking revenge upon the male sex through the beauty and cold-heartedness of this child who was named Estella in the novel. Miss Havisham raised her from childhood to a young girl. Hence she created Estella as a weapon for destruction as she herself has been demolished. 'Let me see you play cards with this boy'. 'With this boy? Why he is a common labouring-boy!.... 'Well? You can break his heart'.... 'Beggar him', said Miss Havisham.” (p.59) Miss Havisham was an example of single-minded woman who was having the mind to take revenge, as a result Miss Havisham and other people in her life did suffer greatly because of her quest of taking revenge. She was so adamant in taking revenge that, she didn't notice about her dreadful actions against Pip and Estella. But towards the end of this novel Miss Havisham did redeem when she realized that she broke Pip's heart and in the same way she has broken her heart as well. She thought she will take revenge on males but instead of that she actually did harm her own self and got much pain. There was no implausibility about asking Pip to forgive her which was the evidence that bad behaviour can be redeemed by Pip for forgiveness, reinforcing the novel's theme towards remorse and empathy. Apart from Estella and Miss Havisham there were other female characters like Biddy, Clara, Mrs. Pocket and Molly those who have their own individual and social stories and expectations. In this novel Great Expectations each of the chief women character was in thirst to seek an identity of the self within a society, which was engulfed with passion, false competition, notion of taking revenge, injustice, greed and cruelty. As a result each of the main characters were isolated yet intertwined with others in a common guilt. Each person was forced to face the negative sides of human nature such as of evil intentions, passion, and pain. Reconciliation and forgiveness come if anyone try to discover the basic aspects in human relationship and understanding, therefore true identity elope from isolation and reach in humanity and compassion. Dickens did portray those female Victorian characters in dramatic ways and hence showed us the ugly face of higher class at that Victorian era. So we can say Dickens got a very in-depth knowledge of the Victorian women and society that is why he succeeded in portraying the realistic picture of Victorian women and social status in Great Expectations.

\section{Conclusion}

To sum up it is almost clear that, Dickens was efficient to depict the Victorian society through some high class women characters in Great Expectations. Miss Havisham who was very wealthy and also she was the lover of power and the notion of taking revenge but didn't get pleasure or self fulfilment after doing all those things. On the other hands Pip also didn't get the sufficient pleasure from his life as a wealthy young man in London. He was getting arrogant after becoming rich and having impoverished life which did lead him towards the degradation of his life. He also stated to do bad behave even with his friend Joe although he felt guilty profoundly. So these were the effects of power and higher class society. The extraordinary thing in Great Expectations, and also this novel 
has been plotted in a very exclusive ways, as the surprising revelation came out regarding Pip's wealth which has been given by the convict Magwitch not Miss Havisham. And this thing radically undermined his sense of selfidentity. The influence of Victorian society ruined Pip, Estella and Miss Havisham's lives. Especially Pip did built up a fantasy of himself but when he suddenly did learn that his criminal past has arrived in the present in the shape of Magwitch, he was almost destroyed and his whole sense of self was contaminated simultaneously and emptied out.

\section{References}

Dickens, C. (1993). Great Expectations. New York : Oxford University Press, 1993.

Allen, W. (1954). The English Novel. London: The Whitfriars Press Ltd., 1954.

Baker, E. A. (1992). The History of the English Novel. Vol. VII, Meerut: Tanmay Prakashan, 1992.

Cecil, D. (2004). Great Novelist of Early Victorian Age. New Delhi: Sangeeta Publication, 2004.

Long, W. J. (2006). English Literature. New Delhi: A.I.T.B.S. Publishers' and Distributors, 2006. Retrieved from http://www.charlesdickens.com

\section{Copyrights}

Copyright for this article is retained by the author(s), with first publication rights granted to the journal.

This is an open-access article distributed under the terms and conditions of the Creative Commons Attribution license (http://creativecommons.org/licenses/by/4.0/). 